\title{
Leading through discontinuous change: a typology of problems and leadership approaches in UK boards
}

Article

Accepted Version

Creative Commons: Attribution-Noncommercial-No Derivative Works 4.0

Morais, F., Kakabadse, A. and Kakabadse, N. (2020) Leading through discontinuous change: a typology of problems and leadership approaches in UK boards. Long Range Planning, 53 (2). 101870. ISSN 0024-6301 doi:

https://doi.org/10.1016/j.Irp.2019.02.003 Available at https://centaur.reading.ac.uk/82273/

It is advisable to refer to the publisher's version if you intend to cite from the work. See Guidance on citing.

To link to this article DOI: http://dx.doi.org/10.1016/j.Irp.2019.02.003

Publisher: Elsevier

All outputs in CentAUR are protected by Intellectual Property Rights law, including copyright law. Copyright and IPR is retained by the creators or other copyright holders. Terms and conditions for use of this material are defined in the End User Agreement.

www.reading.ac.uk/centaur 
Central Archive at the University of Reading

Reading's research outputs online 


\title{
Leading Through Discontinuous Change: A Typology of Problems and Leadership
}

\section{Approaches in UK Boards}

\author{
Dr Filipe Morais@ \\ Post-Doctoral Fellow \\ Henley Business School \\ The University of Reading, \\ Rm EH 510, Greenlands \\ Henley-on-Thames \\ Oxfordshire, RG9 3AU, UK \\ f.m.a.morais@pgr.reading.ac.uk \\ Telephone: (+44) 01491571454 \\ Prof. Andrew Kakabadse ( \\ Professor of Governance and Leadership \\ Henley Business School \\ The University of Reading, \\ Rm EH 500, Greenlands \\ Henley-on-Thames \\ Oxfordshire, RG9 3AU, UK \\ a.kakabadse@henley.ac.uk \\ Prof. Nada Kakabadse $\bigodot$ \\ Head of School - Marketing and Reputation \\ Henley Business School \\ The University of Reading, \\ Rm EH 500, Greenlands \\ Henley-on-Thames \\ Oxfordshire, RG9 3AU, UK \\ n.kakabadse@henley.ac.uk
}

\begin{abstract}
Discontinuous change and leadership behavior are subjects that have been extensively studied, but rarely from the directors' perspective. This study draws on in-depth, elite interviews with directors of large UK listed companies. It applies a grounded theory approach to data analysis, to explore how problems arising from discontinuous change influence board leadership dynamics and outcomes. The findings indicate that, when facing "wicked problems" (internal-
\end{abstract}


relational or external-hostile), the chair of the board either takes the leadership role or a collaborative, joint leadership role with the CEO. When facing "tame" problems (transformational-internal or industry-external), a new CEO is often appointed to undertake an extensive diagnosis of the problem and take the lead, with the chair acting as a vigilant monitor. These findings are integrated into a typology of problems and board leadership approaches, augmenting the literature on complex problems. The study extends the application of agency and stewardship theories of board leadership by characterizing problems as contingencies that influence board leadership arrangements. It follows that regulators and boards alike should recognize the contextual nature of board leadership and leadership succession, and adopt a less prescriptive approach.

KEYWORDS: Discontinuous change; Wicked problems; Tame problems; Board leadership; CEO; Chairperson.

\section{Introduction}

The purpose of this study is to explore how the characteristics of problems that arise from discontinuous change events influence board leadership dynamics and outcomes.

The concept of discontinuous change has been around for several decades (Grundy, 1994; Romanelli and Tushman, 1994; Tushman et al., 1986); it refers to rapid, revolutionary, and frame-breaking change that disrupts existing cultures, structures, and processes, and requires fundamental shifts in order for the business to stay competitive and survive. However, the literature on discontinuous change has, thus far, failed to sufficiently examine several important points. First, it has focused on technological discontinuities (Tushman and Anderson, 1986), while ignoring other, fundamentally different, triggers for discontinuous change, such as 
societal change (Birkinshaw et al., 2016), systemic financial and economic crises, or reputational issues confronting firms - all of which may present leadership with different kinds of problems. Second, there is a paucity of discontinuous change literature examining leadership and internal challenges from the perspective of the board of directors (Hoppmann et al., 2018). While agency theory (Finkelstein and D'Aveni, 1994; Jensen and Meckling, 1976) assigns the CEO the leadership role and the role of vigilant monitor to the board and chair, there are other studies assigning a greater leadership role to the chairperson and the board in times of crisis and far-reaching change (Mizruchi, 1983; Parker, 1990; Taylor, 2001; Withers and Fitza, 2017). In fact, stewardship theorists argue that the chair and CEO roles should be combined as a means of providing unity of command and strategic stability, which is seen to be of particular value when firms are facing difficulties (Donaldson, 1990; Donaldson and Davis, 1991). Third, the approaches presented for leading through discontinuous change are frequently somewhat linear and rationalistic (e.g. Kotter, 1995) — often under the headings of authoritative (Grundy, 1994) or transformational (Bass, 1991) CEO leadership.

This paper attempts to redress these misalignments in the literature and, as such, is underpinned by three questions: a) How do directors perceive problems arising from discontinuous change? b) Who leads through these problems in the context of the board of directors? c) How is leadership exercised?

To answer these questions, this exploratory, qualitative research draws on in-depth elite interviews with directors of large UK listed companies, on the literature on strategic wicked and tame problems (Churchman, 1967; Rittel and Webber, 1973) and employs a grounded approach to data collection and analysis (Corbin and Strauss, 1990; Glaser and Strauss, 1967). This approach to data collection and analysis is particularly useful to investigate weakly understood phenomena and to inductively build new theory from data (Glaser and Strauss, 1967; Spieth et al., 2018). 
Findings indicate that the chair, not the CEO, tends to lead through problems characterized by high wickedness, challenging agency theory's conception of the chair role as that of a vigilant monitor (Finkelstein and D'Aveni, 1994). Evidence suggests that, in leading through wicked problems arising from discontinuous change, chairpersons exhibit a distinct, collaborative leadership style, necessitated by the characteristics of the problem. This lends support to the wicked problem literature, and challenges the discontinuous change leadership literature, which largely proposes transformational leadership styles, led by all-powerful CEOs. In fact, the interviews returned evidence of CEO-led transformational and entrepreneurial leadership styles only when the problems were construed as tame (typically turnarounds, strategic transformations, and new ventures).

The remainder of this paper is structured as follows. First there is a critical review of the literature and research on discontinuous change, strategic "wicked" problems, and board leadership; this is followed by a presentation of the methodology and a detailed presentation of the study findings. The paper continues with a discussion of the findings and their implications for theory, practice, and future research; it closes with a discussion of limitations.

\section{Theoretical background}

\section{Discontinuous change and complex strategic problems}

The study of change has categorized change into a number of types, and identified the leadership style and response most effective for each particular type of change (Ansoff and McDonnell, 1990; Dibella, 2007; Dunphy and Stace, 1993; Grundy, 1994; Nadler et al., 1994; Nadler and Tushman, 1995; Stacey, 1996; Tushman et al., 1986). For example, Tushman et al. (1986) identified three fundamental types of change: i) converging (fine-tuning); ii) converging (incremental); and iii) discontinuous or frame-breaking. Grundy (1994) refers to "smooth 
incremental," "bumpy incremental," and "discontinuous" change. Romanelli and Tushman (1994) describe change as a continuous, incremental process interrupted by periods of revolutionary and discontinuous change. Some more recent work has concentrated on how firms apply different modes of adaptation to discontinuous change (e.g. structural separation, behavioral integration, and sequential alternation) and develop specific higher-order dynamic capabilities which are embedded in the firm's vision, culture, and people development (Birkinshaw et al., 2016). This study focuses on discontinuous or frame-breaking change, characterized by major, rapid (18-24 months), revolutionary changes in strategy, structure, people, and processes, in response to a radically new or different set of circumstances (Tushman et al., 1986), often involving a "divergent break-point" (Grundy, 1994).

Most early models focused on the scale, pace, and complexity of change. However, as globalization has escalated and technological advances have multiplied, the scale and complexity of change events has grown significantly. The increased interdependencies between world economies, brought about by globalization, has made unprecedented "wicked" global crises possible, among them the 2008 financial crisis. Moreover, the emergence of social media, allowing information to flow faster than ever, has rendered businesses more vulnerable to "sticky" reputational crises (Aula, 2010; Tucker and Melewar, 2005). Organizations and business leaders today face challenges of a different nature to those faced by their predecessors. It is therefore important to direct our focus to the nature of the problems that are emerging from novel discontinuous change situations, and look at how leadership is handling them. The literature on wicked and tame problems is an ideal resource with which to frame this discussion.

Problems emerging in the context of uncertainty and complex interdependencies are called "wicked problems" (Churchman, 1967). The concept is believed to have been first used in a public policy context, specifically social planning, to describe and understand insurmountable problems such as unemployment, poverty, and crime (Head and Alford, 2015). 
However, a formal definition was only established some years later when Rittel and Webber (1973) compared and contrasted "wicked" problems with their relatively "tame" counterparts. Tame problems have been described as essentially rational, with a defined solution or set of solutions, clear root causes and clear indicators of success; past experience in handling similar problems is important; the problem definition is therefore not disputed and problem resolution is within the reach of one or two parties to the problem (Rittel and Webber, 1973). Conversely, wicked problems are typically unique, large, and complex, with multiple root causes that are interrelated and difficult to track (Camillus, 2008; Goel, 1992). This makes it difficult to formulate a lasting problem definition (Lyles, 2014). Second, they involve many stakeholders with different priorities and values which present nomological constraints, albeit negotiable, to the problem-solution space (Goel, 1992). In effect, wicked problems are often "associated with social pluralism (multiple interests and values of stakeholders), institutional complexity (the context of inter-organizational cooperation and multilevel governance), and scientific uncertainty (fragmentation and gaps in reliable knowledge)" (Head and Alford, 2015: 716). As such, solutions are a matter of judgment, having no stopping rule, no evaluation function (i.e. they are first-time problems), no immediate feedback, and the consequences are normally severe for those involved (Camillus, 2008; Goel, 1992; Lyles, 2014). Third, as these problems typically take the form of "crisis or social-political problems" (Lyles, 2014), every decision implies complex commitments which are hard to reverse; hence, each attempt towards a solution changes the problem and begets consequences (i.e. there is no opportunity to learn by trial and error) (Camillus, 2008; Goel, 1992). Literature has devoted virtually no attention to tame problems, but there exists a growing literature on leading through wicked problems.

Leadership approaches advocated to address wicked problems differ from those advocated by the discontinuous change literature (Head and Alford, 2015; Roberts, 2000). Roberts (2000) identifies three strategies for handling wicked problems, dependent on the 
power dynamics involved in the problem. When power is concentrated in one or a few stakeholders and accepted as legitimate, "authoritative strategies" are used to tame the problem, since these stakeholders have the authority to define the problem as well as the solution space. However, when power is dispersed, such authority does not lie with any group or person, and so more "collaborative strategies" are required; no one party can unilaterally define the problem and the solution. Collaboration is used in an attempt to minimize costs and maximize gains for different parties, assuming a win-win perspective (Roberts, 2000). When power is not only dispersed but also contested, "competitive strategies" are pursued in an attempt by one party to gain the necessary power to unilaterally define the problem and the solution as it sees fit (Roberts, 2000).

Grint (2008) distinguished between, tame, wicked, and critical problems, respectively associating these with management, leadership, and command approaches. In handling wicked problems, leadership does not know the answer to the problem and, as such, needs to engage the collective in a collaborative process, asking the right questions.

Both the literature and regulations regarding board leadership accord the chair this role of asking the right questions and gaining a better understanding of the problems, the chairperson being tasked with harnessing the contribution of the board as a collective to help define the solution space and challenge the executive's assumptions (Financial Reporting Council, 2011; Kakabadse et al., 2001). The leadership literature has often prescribed some variation of a transformational leadership style, portraying the CEO as the "corporate savior," with the capability to determine the problem and the solution (Currie and Lockett, 2007). It is therefore pertinent to ask whether chairpersons do indeed play a leading role when their organizations experience wicked problems as a result of discontinuous change, or whether the CEO assumes leadership in all types of change scenario. 


\section{Who takes the lead? Board leadership in times of discontinuous change}

Board leadership structure has been a hot topic in governance research. The question of which kind of leadership structure (i.e. combined chair and CEO roles or separate) makes for improved board effectiveness and better firm performance has inspired many studies in recent decades (e.g. Boyd, 1995; Finkelstein and Mooney, 2003; Rechner and Dalton, 1991). Agency theorists (Fama and Jensen, 1983; Jensen and Meckling, 1976) argue that keeping CEO and chair positions separate has a positive effect on the effectiveness of board monitoring and on firm performance, avoiding as it does one-person rule and unfettered decision-making powers for the CEO (Daily and Dalton, 1993; Finkelstein and Mooney, 2003). In this perspective, the chair is depicted as an independent (at least on appointment) and vigilant monitor of CEO behavior, tasked with ensuring that CEO decisions are taken in the best interest of the firm's providers of capital and with due regard for other stakeholders (Coles et al., 2001; Financial Reporting Council, 2016). Separated roles also make for clear CEO accountability to the chairperson and afford the CEO a better opportunity to remain detached and objective (Daily and Dalton, 1993). The UK system of corporate governance has historically been under the influence of agency theory concepts, with role separation in over $99.3 \%$ of FTSE 150 companies (Spencer Stuart, 2017): the UK Code states clearly that the chairperson leads the board and the CEO leads the business (Financial Reporting Council, 2016). In stark disagreement with agency theorists, stewardship theorists (Donaldson, 1990; Lorsch and MacIver, 1990) do not see CEOs inherently self-interested and requiring their performance monitored and controlled by the board. Rather, CEOs are more incentivised to perform well, in line with the interests of the providers of capital; therefore, the role of the board is to collaborate with the CEO to improve decision-making. Collaboration between board and CEO is therefore best achieved when the CEO also occupies the chair position (Donaldson and Davis, 1991). This allows for unambiguous leadership and unity of command, and makes for 
greater stability vis-à-vis policy and strategy (Davis et al., 1997; Donaldson, 1990). The two contrasting theories have been tested over recent decades but with inconclusive results as regards which leadership structure is superior (Boyd, 1995; Finkelstein and Mooney, 2003; Rechner and Dalton, 1991). This uncertainty might be attributed to the fact that boards engage in both control and collaboration depending on the contingencies affecting the company (Albanese et al., 1997; Sundaramurthy and Lewis, 2003). However, the research has remained inconclusive even with the introduction of contingency factors. A combined leadership structure was found to generate a better return on investment for firms in resource-scarce and/or complex environments (Boyd, 1995) yet was found to be associated with worse performance in turbulent environments (Haleblian and Finkelstein, 1993).

In contrast with the governance literature, in change literature the role of the board and, particularly, the chairperson, as effective leaders of change is largely absent. It is possible that it has been accepted as a universal truth that boards are simply rubber-stamps (Mace, 1971) or else "pawns or potentates" (Lorsch and MacIver, 1990); or the concept of a minimalist board holds sway (Pettigrew and McNulty, 1995). Nevertheless, by the 1980s boards were being recognized as having a substantial role to play in policy-making during times of upheaval (Mizruchi, 1983). As Taylor (2001) contends, literature and praxis focus too much on the board's role as a control mechanism and too little on the board as a force for change. It is argued that the board needs to become more of a corporate entrepreneur, "creating the conditions for corporate renewal" (Taylor, 2001: 128).

In the UK, the case has long been made for the chairperson to lead corporate renewal by setting the vision, performance standards, and cultural values that guide the renewal effort (Parker, 1990). More recent studies in the U.S. have found that the chair accounts for up to 9\% variation in firm performance over and above the CEO when firms find themselves in lowmunificence and complex environments (Withers and Fitza, 2017). A study by Krause (2017) 
examined the orientations of U.S. chairs (that were separate from the CEO), and concluded in favor of more collaborative approaches, albeit not a universal finding: one which was contingent on the context of the firm's performance.

Kotter's (1995) paper, on why transformation efforts fail, assigns to the board of directors the role of finding the right CEO to carry out organizational transformation, which presupposes that the board is proactive in identifying the need for change, the elements of change, and the change agent. Like Taylor, Kotter sees as vital the proactive involvement of the board in corporate change:

Poor succession decisions are possible when boards of directors are not an integral part of the renewal effort (Kotter, 1995: 67).

Similarly, Westphal and Fredrickson (2001) show that boards influence strategic change, in response to a firm's poor performance, by appointing a new CEO who is aligned with the strategic change preferences of the directors.

A review of the literature on discontinuous change, strategic wicked problems, and board leadership reveals fundamental disconnections. Figure 1 depicts the conceptual framework developed for this study: 


\section{Figure 1: Theoretical framework}

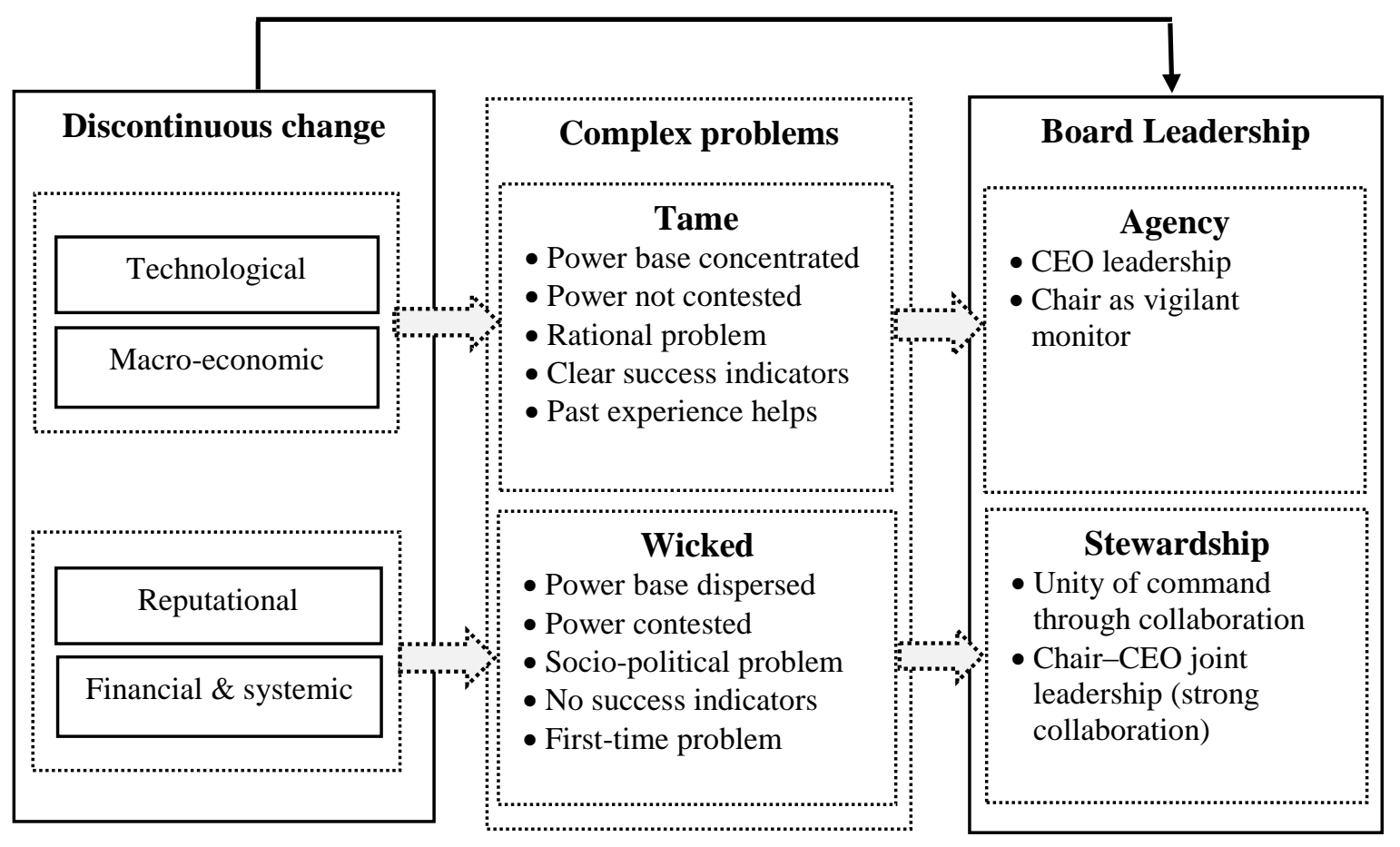

\section{$\longrightarrow$ Existing literature (assumes CEO leadership)}

$\rightarrow$ Proposed theoretical relationships

It is therefore proposed that the board's leadership role and style are influenced by the types of problem (i.e. their characteristics) that emerge from certain discontinuous change events. First of all, we note that most research examining the role of leadership in discontinuous change situations has focused on corporate transformations and turnarounds arising from technological discontinuities (Anderson and Tushman, 1991; Horowitz, 2014), or on how firms can themselves create the next technology disruption (Christensen, 2011). Much less space has been devoted to other types of corporate trauma, e.g. a reputational crisis arising from bribery and corruption allegations or a large, systemic crisis such as the 2008 Global Financial Crisis (GFC), all of which represent large discontinuities for firms. Such corporate traumas may confront leadership with different types of problem (i.e. wicked problems). Second, the leadership and change literature treats CEOs as "masters of the universe," capable of predicting 
and securing the future (Knights and McCabe, 2015), and often prescribes transformational (Sashkin, 2004) or directive/authoritative leadership styles (Grundy, 1994). However, both transformational and directive styles of leadership are called into question in discontinuous change situations that amount to wicked problems: these demand a more collaborative style (Grint, 2008; Head and Alford, 2015; Roberts, 2000). Finally, while the leadership and change literature places the CEO as the unequivocal leader, governance research is less clear as to who takes the lead. Agency and stewardship theories of board leadership, for example, are prescriptive and fail to take into account the particular set of circumstances or problems; these will have implications for how governance and leadership are exercised.

\section{Research design}

\section{Research approach and sample}

This study draws on the theoretical framework presented in the previous section and seeks to explore whether different discontinuous change events confront board of directors with different categories of problem and how this relates to board leadership role and style. The research seeks to establish: i) How do directors perceive problems that arise from discontinuous change? ii) Who leads through these problems in the context of the board of directors? c) How is leadership exercised?

To address these questions, an exploratory qualitative research design was devised (Guba and Lincoln, 2005; Saunders et al., 2009; Silverman, 2013), with data collection based on elite interviewing techniques (Aberbach and Rockman, 2002; Kakabadse and Louchart, 2012) and a grounded approach to data analysis (Corbin and Strauss, 1990; Glaser and Strauss, 1967). The sampling was probabilistic and purposive (Patton, 2002), whereby inclusion criteria were derived primarily from the research framework and questions (Saunders and Townsend, 2016). Participants were selected with the help of a London-based consultancy firm and its network 
of contacts - a firm that had knowledge about which directors had experienced discontinuous events while serving on boards. Directors approached were those with over five years' board experience, and on (or previously on) the board of companies that had undergone significant discontinuous change. An initial list of 20 directors was agreed, and a further 10 were subsequently referred to the research team by some of the initial participants. All 30 agreed to give time for a face-to-face interview. The sample size is in accordance with general guidance for qualitative studies (Creswell, 2007; Saunders and Townsend, 2016) and also in line with the conventions set by similar studies in this area (e.g. Bailey and Peck, 2013; Hendry et al., 2010; Roberts, 2002; Roberts and Stiles, 1999).

Table 1 provides an overview of the sample composition.

Table 1: Sample composition by role

\begin{tabular}{lccccc}
\hline \multirow{2}{*}{ Role type } & $\begin{array}{c}\text { Current } \\
\text { main role }\end{array}$ & $\begin{array}{c}\text { Average } \\
\text { age } \\
\text { (years) }\end{array}$ & $\begin{array}{c}\text { Other } \\
\text { current and } \\
\text { past roles* }\end{array}$ & Mender & F \\
\cline { 4 - 6 } Chief executive officer (CEO) & 17 & 54.7 & 7 & 15 & 2 \\
\hline Chief financial officer (CFO) & 0 & - & 7 & - & - \\
\hline Chairperson & 12 & 61.6 & 9 & 12 & 0 \\
\hline Executive chairperson & 1 & 57.0 & 1 & 1 & 0 \\
\hline Non-executive director (NED) & 0 & - & 9 & - & - \\
\hline Senior independent director (SID) & 0 & - & 3 & - & - \\
\hline Other executive roles & 0 & - & 6 & - & - \\
\hline Totals & $\mathbf{3 0}$ & $\mathbf{5 8 . 0}$ & $\mathbf{4 2}$ & $\mathbf{2 8}$ & $\mathbf{2}$ \\
\hline
\end{tabular}

* Some directors referred to instances of discontinuous change experienced in past board roles or in other current roles. The total current main role experiences along with other current and past roles amount to 72 discontinuous change experiences.

The interviews were conducted in the city of London during 2014. The experiences elicited from the directors took place between 2000 and 2014. Most participants (93.4\%) were male, with an average age of 58. At the time of the study the 17 participants CEOs, 12 were chairpersons and 1 was executive chairperson of large listed firms. All had seats on more than 
one board, having had substantial executive and non-executive experience throughout their careers in a variety of industries, mostly in large FTSE 100 companies (Table 2).

Table 2: Number of board seats per director

\begin{tabular}{lc}
\hline Number of board seats & Number of participants \\
\hline 2 & 17 \\
\hline 3 & 10 \\
\hline 4 & 2 \\
\hline 5 & 1 \\
\hline Total & $\mathbf{3 0}$ \\
\hline
\end{tabular}

Of the companies referred to by participant directors, $80 \%$ had sales of over $£ 1$ billion. Eighteen different industry sectors were discussed in all, the most represented being manufacturing, retail, traditional print businesses, media, music and entertainment, telecom, banking, oil and gas, and energy.

\section{Data collection and analysis}

Participants were asked before the interview to reflect on examples of discontinuous change in which they had been involved as board members. There was no particular stipulation about which industry to focus on, but participants were asked to recall significant and diverse examples of discontinuous change. The key concern was to include a suitable balance of executive and non-executive roles, in order obtain a diverse mix of views about the nature of the problems firms faced and an independent assessment of which directors took the lead in dealing with them. This data collection technique has its limitations with regard to issues of imperfect recall and a tendency for directors to speak as "corporate spokesmen" (McDonald and Westphal, 2010). These limitations were partially mitigated by in-depth desk research, prior to the interview, into each director's career and public records about the events likely to be discussed, along with follow-up questions during the interview itself. Each interview lasted 
between 60 and 90 minutes, was tape-recorded, and subsequently transcribed by a professional agency in order to minimize errors (Bailey and Peck, 2013). Interview themes were derived from the initial literature review, from the research questions, and from a background analysis of the participants' careers. The analysis reached data saturation (the point where no new data emerges that modifies existing categories) at interview 18, but we continued to collect more interview material to ensure the robustness of the coding as well as to benefit from further unique access to high-profile board members (Francis et al., 2010).

The data set was analyzed using the grounded theory method (Corbin and Strauss, 1990; Glaser and Strauss, 1967). Similar approaches to data analysis have been used in previous studies examining board behavior and dynamics (e.g. Bailey and Peck, 2013; Hendry et al., 2010) and chairperson role and leadership (e.g. Roberts and Stiles, 1999). Coding reliability was established by using two coders in the early stages of the analysis (Hendry et al., 2010). Disagreements about coding were resolved by engaging a third researcher in the discussion (Bailey and Peck, 2013). The interview transcripts were read sentence by sentence, and summaries were developed for each reported discontinuous change event in order to gain an initial overall impression of the dataset. Consistent with procedures used in other studies (e.g. Hendry et al., 2010), axial coding was done using the definitions of tame and wicked problems (Camillus, 2008; Goel, 1992; Lyles, 2014; Ritel and Webber, 1973) as sensitizing concepts. A further iteration allowed for a second round of axial coding, which ultimately identified the problem source as either internal or external. Open coding was then used to conceptualize the specific properties of each of the four categories and the contextual conditions, including which director took the lead and the leadership behaviors and styles exhibited. A number of iterations occurred between axial and open coding until the data categories became more clearly delineated. The literature on wicked problems, board leadership, and change was again 
reviewed, this time against the emerging picture, to reinforce its validity. Table 3 provides an overview of the coding process. 
Table 3: Overview of the coding process

\begin{tabular}{|c|c|c|c|c|c|c|}
\hline & \multirow[b]{2}{*}{ Description } & \multicolumn{2}{|c|}{ Axial coding } & \multicolumn{3}{|c|}{ Open coding } \\
\hline & & $\begin{array}{l}\text { Problem } \\
\text { type/ } \\
\text { source } \\
\end{array}$ & $\begin{array}{l}\text { Problem } \\
\text { category }\end{array}$ & $\begin{array}{l}\text { Leadership } \\
\text { role }\end{array}$ & Leadership behavior & $\begin{array}{l}\text { Leadership } \\
\text { style }\end{array}$ \\
\hline \multirow{2}{*}{ 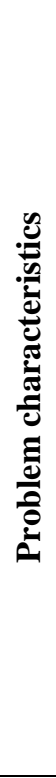 } & 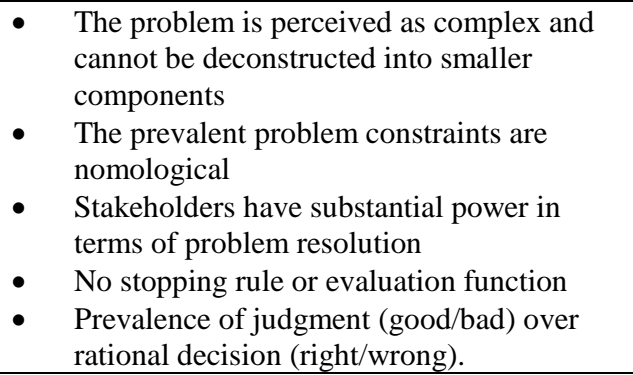 & Wicked (1) & $\begin{array}{l}\text { Internal } \\
\text { wicked } \\
\left(\begin{array}{lll}1 & \times & 3\end{array}\right)\end{array}$ & Chairperson & $\begin{array}{l}\text { - Facilitates investigations } \\
\text { - Makes difficult decisions about people } \\
\text { - Reframes relationships under new } \\
\text { principles and values }\end{array}$ & Relational \\
\hline & $\begin{array}{l}\text { The problem is perceived as complex but } \\
\text { can be deconstructed into smaller } \\
\text { components } \\
\text { The prevalent problem constraints are } \\
\text { logical } \\
\text { - Stakeholders have some power over } \\
\text { problem resolution, but this can be } \\
\text { negotiated logically There is a clear } \\
\text { measure of success and thus a stopping rule } \\
\text { Rational decision-making prevails over } \\
\text { judgment }\end{array}$ & Tame (2) & $\begin{array}{l}\text { External } \\
\text { wicked } \\
(1 \times 4)\end{array}$ & $\begin{array}{l}\text { Chairperson } \\
\text { (sometimes } \\
\text { dyadic } \\
\text { chairperson- } \\
\text { CEO) }\end{array}$ & $\begin{array}{l}\text { - Engages in a constant process of sense- } \\
\text { making about what's going on } \\
\text { - Asks the right questions and engages the } \\
\text { collective board } \\
\text { - Responds radically to threats } \\
\text { - Requires immense emotional resilience }\end{array}$ & Disruptive \\
\hline \multirow{2}{*}{ 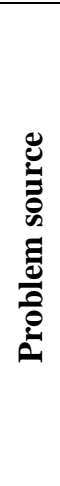 } & $\begin{array}{l}\text { These problems emerged as internal problems } \\
\text { associated with i) company behavior that } \\
\text { damages reputation or relationships with key } \\
\text { stakeholders; ii) a performance problem that lies } \\
\text { within the company. }\end{array}$ & Internal (3) & $\begin{array}{c}\text { Internal } \\
\operatorname{tame}(2 \times 3)\end{array}$ & CEO & $\begin{array}{l}\text { - Defines the business's current and } \\
\text { desired state } \\
\text { - Gets the agreement of critical } \\
\text { stakeholders around a shared purpose } \\
\text { - Develops the plan and executes it } \\
\text { relentlessly }\end{array}$ & Transformational \\
\hline & $\begin{array}{l}\text { These are problems facing the company which } \\
\text { lie in the external environment: i) Problems } \\
\text { arising from external economic and financial } \\
\text { shocks outside the control of the company; ii) } \\
\text { Problems relating to developing new products to } \\
\text { new / existing markets. }\end{array}$ & $\begin{array}{c}\text { External } \\
(4)\end{array}$ & $\begin{array}{l}\text { External } \\
\text { Tame } \\
(2 \times 4)\end{array}$ & CEO & $\begin{array}{l}\text { - Driven by a singular vision of the future } \\
\text { - Great communicators, well-equipped to } \\
\text { energise others and bring people together } \\
\text { to realise a vision. } \\
\text { - Involves founders sharing a vision for the } \\
\text { business }\end{array}$ & Entrepreneurial \\
\hline
\end{tabular}




\section{Results}

\section{Problem type and leadership styles matrix}

Participants reported a total of 72 discontinuous change experiences during their careers as directors. These events took place in the period 2000-14. A number of individuals described different experiences in the same company, which is why these 72 events relate to only $50 \mathrm{UK}$ businesses. The results show that the difficulties facing directors that arise from discontinuous change emerge as a combination of problem complexity and problem source. "Wicked" and "tame" represent the two dimensions of problem complexity, and "internal" and "external" refer to the dimensions of the problem source (Figure 2). A distribution of the 72 discontinuous change experiences according to problem type emerged from the study. The sample comprised directors whom we could confidently say had faced many different discontinuous change events while fulfilling their roles. The resulting distribution is in line with the directors' reported experiences and is plausible in the sense that there is more likelihood of companies

finding themselves in restructuring or turnaround situations than there is of them facing a reputation crisis, or being an "industry disruptor". As such, transformational-internal tame problems $(\mathrm{n}=30)$ were most frequently discussed, followed by relational-internal wicked problems $(n=16)$, hostile-external wicked problems $(n=14)$, and industry-external tame problems $(\mathrm{n}=12)$. 
Figure 2: A matrix of managerial problems arising from discontinuous change and associated leadership styles

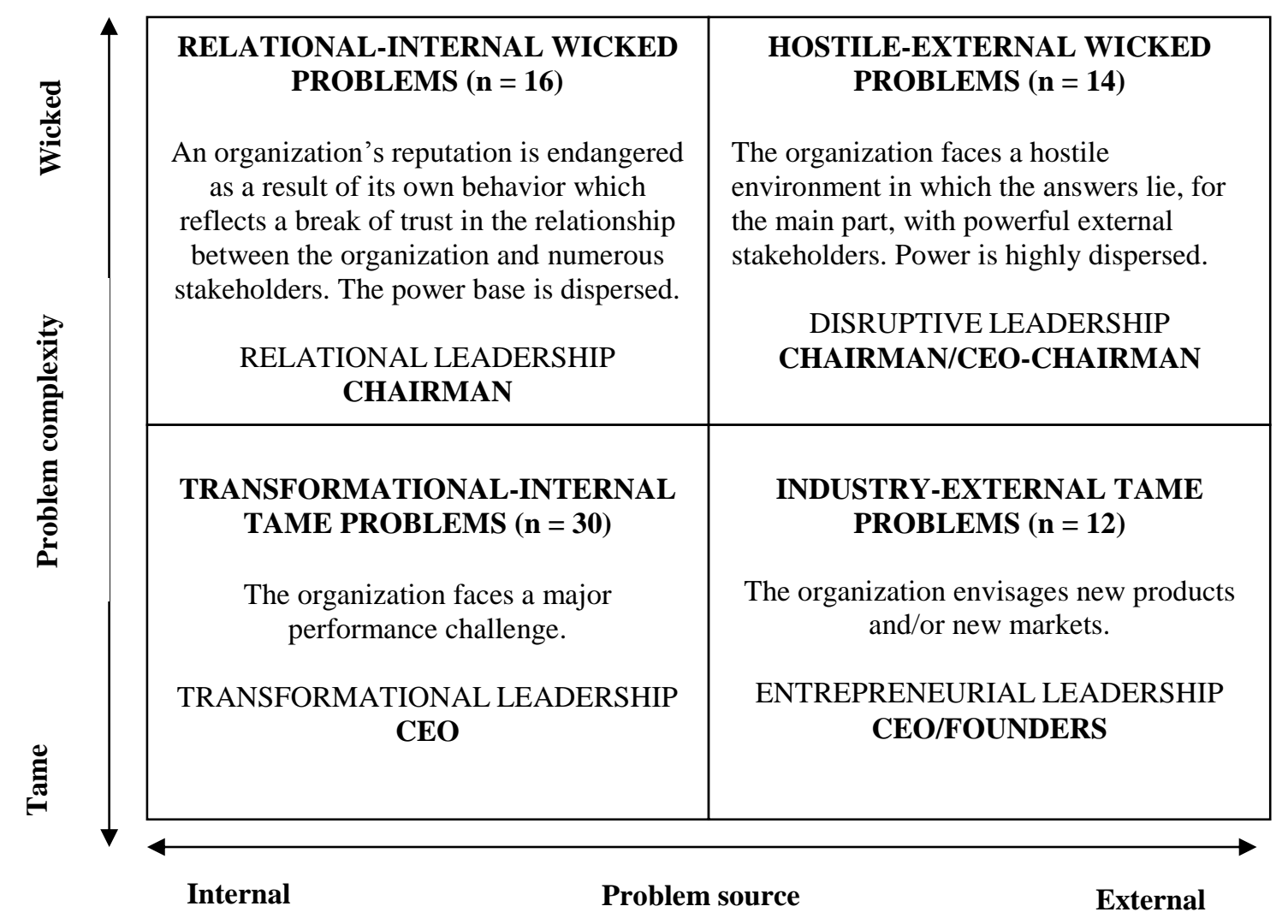

The next sections present detailed results regarding each of the four problem types in terms of their characteristics, salient properties, and leadership role and behavior. The focus is first on those problems that emerged as "tame" (i.e. transformational-internal tame problems and industry-external tame problems), and then on wicked problems (i.e. relational-internal wicked problems and hostile-external wicked problems). The findings are illustrated by examples in the public domain along with selected quotes from the interview material. 


\section{Tame problems: Board leadership role and behavior}

Transformational-internal tame problems. These consist of major performance issues, as a result of poor management decisions and/or inadequate business models which are disrupted by new technology. Extreme problems of this kind have occurred in the music industry, with EMI being a key example in the UK. Thomas Cook plc - the original travel companysuffered a similar, but less severe setback, undergoing a strategic transformation commencing in November 2011, which came as a result of poor acquisition decisions, inadequate organizational structure, and the absence of a digital strategy, all of which begat inefficiencies which became problematic during the Global Financial Crisis and economic recession. In another case, Pearson plc has for several years been undergoing a large digital transformation of its education business. These problems are often attributed to previous management, who were unable to adapt the business to a changing environment and who made a series of poor management decisions. These are by no means easy problems to solve, but the directors who recalled these instances viewed them as tame. They were able to precisely formulate the problem by identifying its components and did not report much in the way of board discussion in relation to defining the problem.

Declining EBITDA from a traditionally declining print business, a business that turned down heavily in a recession and the debt constant especially due to poor acquisitions: it equals a big problem. (CEO)

These situations normally involve the appointment of a new CEO, who undertakes an extensive diagnosis of the problem and then puts a strategic plan in front of the board to recalibrate the company's performance. Data shows that, before accepting the appointment, incoming CEOs often engage in detailed due diligence and gain an accurate picture of the challenges facing the company and the feasibility of rebuilding company performance. Endowed with a mandate from the board and with substantial authority and discretion, CEOs have a substantial power 
base from which to make wide-ranging changes in the business. Interview material shows that the CEO has a substantial amount of clarity and control over outcomes and "the future state" and that prior experience in leading turnarounds and strategic transformations is highly valuable. Interview material also shows that, although there are multiple stakeholders, these will normally share a common vested interest in the company's survival and the position of each party is usually known and negotiable. Virtually all directors who experienced transformational-internal tame problems, according to our typology, ascribed the leadership role to the CEO. Leadership behaviors point towards a transformational leadership style and include the diagnosis of the problem, the definition of a vision or end state, the engagement, agreement, and alignment of key stakeholders, and the relentless execution of a strategic plan developed by the CEO and his/her team and approved by the board. The strategic plan would normally include an expression of a generic competitive advantage (i.e. cost leadership, innovation leader) which would guide initiatives of cost reduction and asset retrenchment.

... we do rough stuff, and getting the sequence right and bringing people, people will follow you anywhere through any hardship as long as they know eventually you get to the sunny outburst. So set out the journey and set out the end point as a vision, somewhere we want to get to and they'll follow you through anything and help you deliver it. (CEO)

In addition to the above, a common aspect of CEO behavior throughout this problem type was to energize all employees, through constant communication across the organization about the plan and the vision for the company.

All this change is not nice: there's people losing their jobs, etc., and, but they'll endure anything as long as they know that they're doing it because there's a reason, there's a mandate in the first place, there was an event, a crisis, a trauma and the management have taken that trauma and exploded it and explained it to people and they're going to move on. The danger is the management or the board that wants to play down the crisis, externalize it, play it up. (CEO) 
Interview material also indicates the presence of clear indicators of success or failure. The endpoint of the turnaround or transformation effort was clearly flagged by CEOs and recognized by other stakeholders.

Industry-external tame problems. This category refers to the more common discontinuity situation in which the company itself is the disruptor. A planned or emergent idea is developed, such as a new product or technology for an existing or new market; this then disrupts existing operations or stakeholders outside the company. Examples include first movers with innovative business models such as: lastminute.com, which revolutionized holiday, travel, and tourism; Spotify and iTunes, which toppled traditional music providers; Alibaba Group Holdings Ltd in China, which is now the country's biggest seller of money market funds; or, more recently, Uber which revolutionized transport solutions. An analysis of the interview material indicates that CEOs/founders lead through these problems which are portrayed as difficult but tame. Although there is an element of the unknown, the leader has a positive guiding vision and faces a low downside risk. Leadership behavior includes the development of a clear, innovative vision of the world, which is then pursued and communicated through some form of entrepreneurial leadership. These scenarios often become success stories in which a company sets new benchmarks for its sector.

... we spent a huge amount of time playing, effectively, a small leadership role in the industries that we were trying to disrupt, which is slightly unusual but I think maybe that's what happens when you start something in such a new media. It's slightly different because you start with nothing, so you are not transforming from $A$ to $B$, but you are creating something new. (Co-founder)

Leadership was found to be driven by a single, innovative vision of the future. Typical behaviors also included relentless communication of the vision to internal and external 
stakeholders, an ability to inspire and energize others and bring people together to realize the vision, and an encouragement of experimentation throughout the company.

... we just had a kind of relentless message of: the world is changing, this is a big opportunity for you, you can make more money, and if you don't get on board you're going to lose money anyway, so come and join us and give it a whirl. There is no secret science to this: it's not some massive thing that gets suddenly revealed to you-you're just passionate about your products, and obsessive about it, and will talk about it anywhere and do anything it takes to encourage people to try it, use it, work with you. (CEO)

\section{Wicked problems: Board leadership role and behavior}

Relational-internal wicked problems. These typically originate in cases involving organizational misconduct or fraud allegations, disrupting relationships with critical internal and external stakeholders (e.g. society, government, customers, the top leadership team). They arise from a company's own behavior (internal) which has brought it into disrepute and can ultimately threaten its license to operate and, therefore, its very survival. The media have been full of these kinds of problem. Past examples include: the Al Yamamah bribery allegations against BAE Systems in the 2000s with the Serious Fraud Office and the U.S. Department of Justice questioning the company's license to operate; the allegations against GlaxoSmithKline which led to an unwanted restructuring in its U.S. operations and billions of pounds lost. More recent examples are: the case of Wells Fargo's fake accounts and consequent loss of consumer trust; Samsung's corruption allegations; the Volkswagen emissions scandal; and Toshiba and Tesco's inflated accounts. To different degrees, all these crises have damaged these companies' reputations and relationships with key stakeholders. How the companies' respective boards dealt with them also varied immensely. The interview data has brought evidence of a number of the characteristics of wicked problems in these instances. Typical expressions from the directors included: "it's extremely difficult"; "the problems still persist as a result"; "you can 
never declare victory"; "we never encountered this before: what our institutional response would be?"; and "it was unrelated to you at the beginning but at the end everything is related to you." Such remarks underscore a number of wicked-problem properties such as their sociopolitical nature, their uniqueness, the impossibility of drawing from previous experience, the lack of clear right or wrong responses, and the shifting nature of the problems.

So how difficult is this? Quite difficult, but it's about seeing it through and being completely consistent to make that cultural change work. And it is an area where you can never declare victory. (Chairperson)

... all of the sudden ... what had happened was vile and it, I could see that the reputation was damaged and what it could do to the company would take a huge amount of scrubbing to remove and indeed the stains have proved very stubborn. The company still has reputational issues which have come out of this, just as bad as things could be in every possible way. (Chairperson)

... and were horrified and, again, this is again an example of discontinuous change: we never discovered this before-what should our institutional response have been? (Chairperson)

So issues start in the real world and they explode and they end in the political world. ... it's a bit like a rocket, you start off in the ground but by the time you've gone through six or seven layers of the stratosphere, you have to deal with each layer, and each layer has a different issue to resolve, have nothing to do with the start. It was unrelated to you at the beginning, but by the end it's all related to you. (CEO)

Directors involved in these kinds of problem revealed that leadership is often assumed by the chairperson, who will use his/her position to reassure shareholders and other critical stakeholders and then seek their collaboration, in an effort to mend the company's image and reputation. The interviews reveal collaborative approaches by chairpersons, which often mean substantially more board involvement and more board meetings, with the chairperson taking the lead in negotiating terms with external stakeholders. The chair also leads in reframing the company's relationships under changed principles and values, often by changing the culture at the top and right through the organization. This includes removing individuals from key 
positions and reviewing internal controls. It is not uncommon for a board committee to be formed to address the problem, led by the chairperson.

They went out of their way to praise the way that we had behaved and how much we cooperated, and they used words like "model," "exemplary," "cooperation"-actually unheard of. (Chairperson)

That's been difficult, but interestingly what's happened is that some healthcare practitioners, whose doors were closed and are closed to everyone in the pharma industry, now feel much more comfortable about talking to us than talking to others. (Chairperson)

As such, with the focus of this relational leadership style being to re-establish trust in the relationships between the company and its critical stakeholders, the chairperson collaborates extensively both internally and externally to regain credibility and trust. The chair is often best placed to disrupt existing relationships and set the framework within which the company will conduct itself in the future. Creating bridges, consensus, and trust are seen as requirements that fit uniquely with the chair's leadership.

Hostile-external wicked problems. In this category, problems are both highly unpredictable and pose a serious threat to the survival of the organization or industry. Hostile-external wicked problems are primarily related to the troubles encountered by banks and other firms during the height of the 2008 Global Financial Crisis. These are panic situations. Examples are: HBOS's crisis and subsequent takeover by Lloyds and the events that followed; the ongoing problems of Royal Bank of Scotland (RBS) since the 2008 crisis; and the Lehman Brothers collapse and how it was dealt with by CEO Dick Fuld and Lehmans' board. Others include hostile takeovers such as the recent failed attempt of Kraft Heinz to acquire Unilever, which immediately took on a political dimension and had implications for Unilever's future plans. Past examples include the Pfizer and AstraZeneca takeover fight, and the Nasdaq OMX/IntercontinentalExchange attempt to undermine Deustche Boerse's bid to buy the NYSE 
and the subsequent regulatory involvement. Brexit may well foment the next crisis for many UK firms. Interview evidence shows how directors discussing such situations typically refer to the absence of a clear sense of right or wrong, coupled with a lack of control. Expressions such as "uncharted territory," "unique situation," "systemic," "no one knew what to do," and "intractable" were commonly used. Equally evident was the presence of large, powerful stakeholders such as central banks, the government, regulators, and large institutional shareholders - all with a significant sway over how the problem was defined and handled.

It just kept getting worse, and the terrifying thing was nobody could see the bottom ... we were in completely uncharted territory: no one had been through this before so no one knew what to do, they really didn't ... (Chairperson)

trying to find a way through it as much as you possibly could, but that was probably one of those intractable problems that can you never really solve to the benefit of everybody, because the challenge was greater ... It just, there were just too many players chasing too many things. (Chairperson)

Leadership under these circumstances has been attributed by the directors in this study to the chairperson or to the chair and CEO acting in tandem. The leadership behavior here is collaborative in the sense that there is a continuous assessment of the problem, which is undertaken collectively by the board. A process of constant sense-making of events as they unfolded, with a dramatic increase in the number of board meetings and board calls led by the chairperson, was the norm. The interview material revealed that dramatic decisions and shifts in thinking occurred, based on little or no information. On those occasions where a more shared leadership approach was taken, chairs and CEOs exhibited a united front, and jointly committed to highly risky courses of action in an attempt to address the problem. There are strong parallels between this kind of leadership behavior and a game of poker. The stakes were high and there were lots of attempts to test reality (e.g. by issuing a statement to test the reaction of other stakeholders and then acting, based on that new information). As such, this disruptive 
leadership style involves high-risk bets with no clear idea of right or wrong; it has been described as requiring high doses of emotional resilience.

[Non-executive directors] actually felt part of the team and they spoke up and they said, "Why don't we do this and what happens if we do that?" And so I had to make a number of absolutely massive decisions by any standards-life-threatening decisions. (Chairperson)

The CEO was overcome by passion; in other words, he was so mortified, horrified, hurt at the thought that his toy, his baby, was going to be snatched away from him and he'd felt it very, very deeply and that colored his judgment, colored his judgment ... and I had to take a much more leadership role than I thought I would. (Chairperson)

Problem categorization based on the data is not static, however. A number of the reported problems started as a hostile or relational issue and gradually become a transformational effort. The leadership styles and sources described below therefore require adjustment as the problem evolves.

\section{Discussion and implications}

Our findings add to the literature on complex problems (Camillus, 2008; Grint, 2008; Head and Alford, 2015; Roberts, 2000) by developing an empirical matrix of four problem types and corresponding leadership styles as well as a first account of how complex problems are perceived and handled in the context of boards of directors.

While the literature accords to the board a role in enabling the firm to adapt to environmental discontinuities, there is little work on a board's internal challenges and dynamics: what there is often focuses on board composition renewal as an adaptive mechanism (Hillman et al., 2000; Hoopmann et al., 2018). Less attention still has been directed at understanding board leadership during environmental discontinuities. This is partly because the literature has been driven by agency theory's assumption that, in separated board leadership structures, the chair assumes a control function, acting as a vigilant monitor (Finkelstein and D'Aveni, 1994; Krause, 2017; 
Sundaramurthy and Lewis, 2003). It was also driven by a portrayal of the CEO as "master of the universe" (Currie and Lockett, 2007; Knights and McCabe, 2015), or of dominant CEOs as saviors of troubled firms (Fralich and Papadopoulos, 2018; Tang et al., 2011; Tang and Crossan, 2017). In addition the more general change literature has depicted the board's influence as being limited to the act of hiring the CEO (Kotter, 1995; Westphal and Fredrickson, 2001). Our results help to clarify the board leadership literature by showing that "who leads" is contingent on the nature and type of problem being faced by the firm. In this sense, we are adding to contingency theories of corporate governance generally (Hillman and Dalziel, 2003; Lynall et al., 2003) and of board leadership specifically (Boyd, 1995; Haleblian and Finkelstein, 1993) by examining the nature of problems as contingencies that influence board leadership in separated leadership structures. The extant literature that treats CEOs as "masters" and "saviors," leading firms through discontinuous environments (Knights and McCabe, 2015; Tang and Crossan, 2017), and agency predictions of chairs behaving as vigilant monitors (e.g. Sundaramurthy and Lewis, 2003), hold only when the complex problems being faced by the firm are well defined, when there are clear indicators of success, and when the firm's power base is solid: that is, when the problems are tame. In these instances (i.e. transformational-internal tame problems), a new CEO is often appointed to undertake an extensive diagnosis of the problem and lead the formulation and implementation of a strategic plan as a response. In contrast, we find that chairs move away from the "vigilant monitor" function to assume leadership and adopt a more collaborative approach when problems have a more socio-political nature, are undefined and unclear, and where their resolution lies with a range of external powerful stakeholders: that is, when problems are wicked. Table 4 summarizes this study's contributions to knowledge. 
Table 4: Contributions to knowledge

\begin{tabular}{|c|c|c|c|c|c|}
\hline $\begin{array}{l}\text { Research } \\
\text { questions }\end{array}$ & $\begin{array}{l}\text { Wicked } \\
\text { problems }\end{array}$ & $\begin{array}{l}\text { Tame } \\
\text { Problems }\end{array}$ & Agency theory & $\begin{array}{l}\text { Stewardship } \\
\text { theory }\end{array}$ & This study \\
\hline $\begin{array}{l}\text { Who leads } \\
\text { through } \\
\text { problems } \\
\text { arising from } \\
\text { discontinuous } \\
\text { change? }\end{array}$ & $\begin{array}{l}\text { Not specific } \\
\text { about who } \\
\text { leads, but } \\
\text { implicitly } \\
\text { assumes CEO } \\
\text { leadership } \\
\text { (e.g. Grint, } \\
\text { 2008; Roberts, } \\
\text { 2000) }\end{array}$ & $\begin{array}{l}\text { No specific } \\
\text { literature exists } \\
\text { that examines } \\
\text { tame problems } \\
\text { leadership. }\end{array}$ & $\begin{array}{l}\text { The CEO leads } \\
\text { and the } \\
\text { chair/board are } \\
\text { vigilant monitors. } \\
\text { The board chair } \\
\text { scrutinizes the } \\
\text { CEO's proposals } \\
\text { for restoring } \\
\text { performance, asks } \\
\text { questions, and } \\
\text { monitors } \\
\text { performance } \\
\text { (e.g. Finkelstein }\end{array}$ & $\begin{array}{l}\text { The chair and } \\
\text { CEO positions } \\
\text { should be } \\
\text { occupied by the } \\
\text { same individual } \\
\text { to provide unity } \\
\text { of command, } \\
\text { unequivocal } \\
\text { leadership and } \\
\text { favor strategic } \\
\text { stability and } \\
\text { long-term } \\
\text { orientation. }\end{array}$ & $\begin{array}{l}\text { Depends on the problem } \\
\text { characteristics: } \\
\text { Wicked problems } \\
\text { (relational or hostile): the } \\
\text { chair takes the lead, } \\
\text { sometimes in tandem with } \\
\text { the CEO. } \\
\text { Tame problems } \\
\text { (transformational or } \\
\text { industry): the CEO } \\
\text { always takes the lead, and } \\
\text { the chair/board are } \\
\text { vigilant monitors. }\end{array}$ \\
\hline $\begin{array}{l}\text { How is } \\
\text { leadership } \\
\text { exercised? }\end{array}$ & $\begin{array}{l}\text { Authoritative, } \\
\text { collaborative, } \\
\text { or competitive } \\
\text { depending on } \\
\text { power base } \\
\text { and whether it } \\
\text { is contested } \\
\text { (Roberts, } \\
\text { 2000) } \\
\text { Collaborative: } \\
\text { asking the } \\
\text { right } \\
\text { questions } \\
\text { (Grint, 2008) }\end{array}$ & & $\begin{array}{l}\text { and D'Aveni, } \\
\text { 1994; } \\
\text { Sundaramurthy } \\
\text { and Lewis, 2003) }\end{array}$ & $\begin{array}{l}\text { (e.g. Davis et } \\
\text { al., 1997; } \\
\text { Donaldson, } \\
\text { 1990) }\end{array}$ & $\begin{array}{l}\text { Depends on the nature of } \\
\text { the problem and its } \\
\text { complexity } \\
\text { (tame/wicked). } \\
\text { Wicked problems require } \\
\text { collaborative leadership } \\
\text { which can assume a } \\
\text { relational or a disruptive } \\
\text { style. } \\
\text { Transformational and } \\
\text { entrepreneurial styles } \\
\text { are often found when } \\
\text { CEOs are facing } \\
\text { transformational and } \\
\text { industry-tame problems. }\end{array}$ \\
\hline
\end{tabular}

Our findings also shed light on how board leadership is exercised. While the extant literature prescribes some form of transformational (Bass, 1991; Kotter, 1995; Sashkin, 2004) or entrepreneurial (Covin and Slevin, 1991; Kuratko and Hodgetts, 2007) leadership style, to be exercised by the CEO with the chair left to assume a non-collaborative control function (Finkelstein and D'Aveni, 1994; Jensen and Meckling, 1976; Sundaramurthy and Lewis, 2003), our study shows that the argument about the chair's control and/or collaborative leadership styles (e.g. Sundaramurthy and Lewis, 2003) requires a consideration of the type of problem being faced and not just the effect of past performance (Krause, 2017). Our findings 
evidence a more collaborative leadership style being adopted by the chair when problems are wicked (i.e. hostile-wicked and relational-wicked problems in our matrix). We have shown that, in these cases, the leader needs to collaborate extensively with external powerful stakeholders, such as central banks, governments, and regulators, in an attempt to regain their trust and support. Chairs that led through relational-internal wicked problems exhibited a relational style of leadership. Defined as a "relational practice of collaboration, empathy, trust, empowerment ... something actors 'do' within social interactions and networks of influence to construct realities" (Cunliffe and Eriksen, 2011: 1430), relational leadership has also been described as "creating opportunities for relationally-responsive dialogue" through "relational integrity" in working through differences in stakeholder dialogue (Cunliffe and Eriksen, 2011: 1433-1439). In leading, both internally and externally, the chair recognizes that leadership is a process exercised within a network of relations, contributing to the creation of a new reality and understanding (i.e. of the organization's license to operate, its reputation, and its image), co-created with other stakeholders (Cunliffe and Eriksen, 2011; Uhl-Bien, 2006). Chairs would often increase the number of meetings involving the whole board, often with a dedicated committee being formed to handle relationships with the media and stakeholders; internally, the chairperson also leads the process of reviewing company principles and values and sets a clear direction for the company in changing structure, process, and culture so as to meet legal and regulatory requirements and, importantly, social expectations; the chair facilitates internal investigations and makes difficult decisions about key people. In the case of hostile-external wicked problems, there is also a strong requirement for collaborative leadership. Notwithstanding the foregoing, the focus of the chairperson (or the chair-CEO dyad) remains on collective sense-making of the problems as they unfold (Weick et al., 2005) and his/her importance rests in an ability to undertake dramatic shifts in thinking and to use judgment to effect large changes in the organization. Inevitably, this means the organization will lose 
something in exchange for stability and future prosperity. Chairs (and sometimes pairs of chair-CEOs) were found to dramatically increase the number of board meetings and board calls, with the board as a whole engaged in interpreting a continuous flow of events, and were found to shift their thinking and action as required by the evolving circumstances. This portrayal of a distinct collaborative chair leadership style provides a more nuanced picture of chair behavior in particular contexts, adding to the literature describing chair behavior and contribution.

In addition to the theoretical contributions and implications discussed above, this paper has some practical implications and usefulness. The UK Corporate Governance Code rests on the premises of agency theory as regards board leadership: the chair should be independent on appointment and perform the role of vigilant monitor of the CEO's conduct. This separated leadership structure ensures clear accountability, enabling the CEO to focus on running the business and the chair to lead the board of directors (Financial Reporting Council, 2011, 2016). Furthermore, the Financial Reporting Council Guidance on Board Effectiveness (2011) lays down a requirement that the "chairman and the CEO roles should be set out in writing and agreed by the board" and "particular attention [should be] paid to areas of potential overlap" (Financial Reporting Council, 2011: 7). These recommendations are challenged by the current study in that, during periods of corporate trauma, and especially when emerging problems are "wicked" in nature, there is a requirement for leadership to be more problem-focused and less accountability-focused. Role arrangements that are "set out in writing" provide accountability, but perhaps a (false) sense of security that may impede the board from adapting to evolving wicked problems, requiring as they do greater collaboration and, ultimately, a different source and style of leadership. This paper does not dispute that a separation of chair and CEO roles is preferable as it provides greater options for addressing corporate problems. However, the code should recognize that there is no single optimum way to agree role arrangements between chair 
and CEO, and that this will be dependent on the context and types of problem facing the firm at any given moment. Our findings and insights may be useful for boards who are faced with succession decisions or decisions about leadership through particular problems. The evidence that dominant CEOs might not be appropriate for problems characterized by "wickedness" is important in developing leaders who will be able to operate in an increasingly wicked world. Finally, boards and practicing directors may benefit from a framework of problems and leadership approaches and also from an appropriate language to guide them through discontinuous change scenarios.

In conclusion, this study adds to the behavioral and contextual perspectives of board leadership and to the important debate concerning the application of agency and stewardship theories.

\section{Limitations and future research}

This study has some limitations, some of which may be resolved in future studies. It is based on a robust yet relatively small sample of directors of UK listed firms. While our research question was not related to a director's gender, it would have been useful to have had a more gender-balanced sample. However, it is worth noting that FTSE 100 companies have a very limited number of directors in the positions of CEO and chair, for example. Our research design did not allow for a capture of how complex problems and leadership dynamics co-evolve; this would have allowed a richer insight into the contextual and dynamic nature of board leadership. Future studies could concentrate on exploring, possibly through case study, how relationalinternal and hostile-external wicked problems change and co-evolve into different categories of problem, and the extent to which board leadership adapts to such an evolution.

Second, boards in the UK are unitary and the vast majority have separate roles for chairperson and CEO. Future research could therefore seek to test these results in a different 
context (e.g. Germany) and see whether different patterns emerge. Currently, there is limited scope to generalize these findings to other governance regimes.

Finally, insights emerging from this study may prove useful from the perspective of the board's role in strategy and the strategy-as-practice literature (Hendry et al., 2010; Pugliese et al., 2009). Our findings indicate that boards use "interactive strategizing," primarily when the problems are wicked, and "procedural strategizing" when the problems are tame (Jarzabkowski, 2005). A wicked problem has no clear definition and there is no definite plan; the chair engages the collective to continuously assess the problem and produce tentative responses on an ongoing, interactive basis, as things evolve. Chairs and other directors reported a surge in board live strategizing, with as many as 30 board meetings in a year and a variety of board calls. In contrast, when facing tame problems, this study suggests that 'procedural strategizing' is preferred, with the board adopting a close and vigilant monitoring role with regard to the plan devised by the CEO and his/her team. Hendry et al. (2010) showed in their study that a prevalence of one or the other form of strategizing is dependent on i) the relative power balance between the board and management; ii) the board's strategic stance; and iii) practice legitimacy. Considering board strategizing from a wicked-problem perspective allows us to extend our consideration of the power balance beyond board management to other stakeholders; wicked problems may also alter the perceived and dominant practice legitimacy of the board.

In summary, it is hoped this study brings a fresh perspective that sparks new debates and opens up new avenues of inquiry that can enrich the academic and practitioner communities understanding of board leadership. 


\section{REFERENCES}

Aberbach, J.D., Rockman, B.A., 2002. Conducting and coding elite interviews. Political Science \& Politics, 35 (4), 673-676.

Albanese, R., Dacin, T.M., Harris, I.C., 1997. Agents as stewards. Academy of Management Review, 22 (3), 609-611.

Anderson, P., Tushman, M.L., 1991. Managing through cycles of technological change. Research-Technology Management, 34 (3), 26-31.

Ansoff, I.H., McDonnell, E.J., 1990. Implanting Strategic Management. Prentice Hall, New York.

Aula, P., 2010. Social media, reputation risk and ambient publicity. Strategy and Leadership, $38(6), 43-49$.

Bailey, B.C., Peck, S.I., 2013. Boardroom strategic decision-making style: Understanding the antecedents. Corporate Governance: An International Review, 21 (2), 31-146.

Bass, B.M., 1991. From transactional to transformational leadership: Learning to share the vision. Organizational Dynamics, 18 (3), 19-31.

Birkinshaw, J., Raisch, S., Ziermmermann, A., 2016. How do firms adapt to discontinuous change? Bridging the dynamic capabilities and ambidexterity perspectives. California Management Review, 58 (4), 36-58.

Boyd, B.K., 1995. CEO duality and firm performance: A contingency model. Strategic Management Journal, 16 (4), 301-312.

Camillus, J. C., 2008. Strategy as a wicked problem. Harvard Business Review, 86 (5), 99106.

Christensen, C.M., 2011. The Innovator's Dilemma: The Revolutionary Book that Will Change the Way You do Business. Harper Collins, New York.

Churchman, C.W., 1967. Wicked problems. Management Science, 14, B141-B142. 
Coles, J.W., McWilliams, V.B., Sen, N., 2001. An examination of the relationship of governance mechanisms to performance. Journal of Management, 27 (1), 23-50.

Corbin, J., Strauss, A.L., 1990. Grounded theory research: Procedures, canons, and evaluative criteria. Qualitative Sociology, 13 (1), 13-19.

Covin, J.G., Slevin, D.P., 1991. A conceptual model of entrepreneurship as firm behavior. Entrepreneurship Theory \& Practice, 16 (1), 7-25.

Creswell, J., 2007. Qualitative Inquiry and Research Design: Choosing among Five Approaches, second ed. Sage, Thousand Oaks, CA.

Cunliffe, A.L., Eriksen, M., 2011. Relational leadership. Human Relations, 64 (11), 14251449.

Currie, G., Lockett, A., 2007. A critique of transformational leadership: Moral, professional and contingent dimensions of leadership within public services organizations. Human Relations, 60 (2), 341-370.

Daily, C.M., Dalton, D.R., 1993. Board of directors leadership and structure: Control and performance implications. Entrepreneurship: Theory and Practice, 17 (3), 65-82.

Davis, J.H., Schrooman, F.D., Donaldson, L., 1997. Towards a stewardship theory of management. Academy of Management Review, 22 (1), 20-47.

Dibella, A.J., 2007. Critical perceptions of organisational change. Journal of Change Management, 7 (3-4), 231-242.

Donaldson, L., 1990. The ethereal hand: Organizational economics and management theory. Academy of Management Review, 15 (3), 369-381.

Donaldson, L., Davis, J.H., 1991. Stewardship theory or agency theory: CEO governance and shareholder returns. Australian Journal of Management, 16 (1), 49-65.

Dunphy, D., Stace, D.A., 1993. The strategic management of corporate change. Human Relations, 46 (8), 905-920. 
Fama, E.F., Jensen, M.C., 1983. Separation of ownership and control. Journal of Law and Economics, 26 (2), 301-325.

Finkelstein, S., D’Aveni, R.A., 1994. CEO duality as a double-edged sword: How boards of directors balance entrenchment avoidance and unity of command. Academy of Management Journal, 37 (5), 1079-1108.

Finkelstein, S., Mooney, A.C., 2003. Not the usual suspects: How to use board process to make boards better. The Academy of Management Executive, 17 (2), 101-113.

Financial Reporting Council, 2011. FRC Guidance on Board Effectiveness. Retrieved May, 30, 2016 from: https://www.frc.org.uk/Our-Work/Publications/Corporate-

\section{Governance/Guidance-on-Board-Effectiveness.pdf}

Financial Reporting Council, 2016. The UK Corporate Governance Code. Retrieved September, $\quad 10, \quad 2016 \quad$ from: $\quad$ https://www.frc.org.uk/OurWork/Publications/Corporate-Governance/UK-Corporate-Governance-Code-April2016.pdf

Fralich, R., Papadopoulos, A., 2018. The financial crisis, acquisition premiums and the moderating effect of CEO power. Long Range Planning, 51 (2), 204-218.

Francis, J.J., Johnston, M., Robertson, C., Glidewell, L., Entwistle, V., Eccles, M.P., Grimshaw, J.M., 2010. What is an adequate sample size? Operationalising data saturation for theory-based interview studies. Psychology and Health, 25: 1229-1245.

Glaser, B.G., Strauss, A.L., 1967. Discovery of Grounded Theory: Strategies for Qualitative Research. Aldine Publishing, Chicago.

Goel, V., 1992. Comparison of well-structured and ill-structured task environments and problem spaces. Paper presented at the $14^{\text {th }}$ Annual Conference of the Cognitive Science Society, Erlbaum, Hillsdale, NJ. 
Grint, K., 2008. Wicked problems and clumsy solutions: The role of leadership. Clinical Leader, 1 (2), 54-68.

Grundy, T., 1994. Implementing Strategic Change: A Practical Guide for Business, Kogan Page, London.

Guba, E.G., Lincoln, Y.S., 2005. Paradigmatic controversies, contradictions, and emerging confluences, in: Denzin, N.K., Lincoln, Y.S. (Eds.), The Sage Handbook of Qualitative Research, third ed. Sage, London, pp. 191-216.

Haleblian, J., Finkelstein, S., 1993. Top management team size, CEO dominance, and firm performance: The moderating roles of environmental turbulence and discretion. Academy of Management Journal, 36 (4), 844-863.

Head., B.W., Alford, J. 2015. Wicked problems: Implications for public policy and management. Administration \& Society, 47 (6), 711-739.

Hendry, K.P., Kiel, G.C., Nicholson, G., 2010. How boards strategise: A strategy as practice view. Long Range Planning, 43 (1), 33-56.

Hillman, A.J., Cannella, A.A., Paetzold, R.L. 2000. The resource dependence role of corporate directors: Strategic adaptation of board composition in response to environmental change. Journal of Management Studies, 37 (2): 235-256.

Hillman, A.J., Dalziel, T. 2003. Board of directors and firm performance: Integrating agency and resource dependence perspectives. Academy of Management Review, 28 (3): 383396.

Hoppmann, J., Naegele, F., Girod, B. 2018. Boards as source of inertia: Examining the internal challenges and dynamics of boards of directors in times of environmental discontinuities. Academy of Management Journal, published online May 10, 2018, https://doi.org/10.5465/amj.2016.1091 
Horowitz, B., 2014. The Hard Thing About Hard Things: Building a Business When There Are No Easy Answers. Harper Collins, New York.

Jarzabkowski, P., 2005. Strategy as Practice: An Activity-Based View. Sage, London.

Jensen, M.C., Meckling, W.H., 1976. Theory of the firm: Managerial behaviour, agency costs and ownership structure. Journal of Financial Economics, 3 (4), 305-360.

Kakabadse, A., Ward, K., Kakabadse, N., Bowman, C., 2001. Role and contribution of nonexecutive directors. Corporate Governance: The International Journal of Business in Society, $1(1), 4-8$.

Kakabadse, N.K., Louchart, E.S., 2012. Delicate empiricism: An action learning approach to elite interviewing, in: Kakabadse, A.P., Kakabadse, N.K. (Eds.), Global Elites: The Opaque Nature of Transnational Policy Determination. Palgrave Macmillan, Basingstoke, pp. 286-307.

Knights, D., McCabe, D., 2015. Masters of the universe: Demystifying leadership in the context of the 2008 Global Financial Crisis. British Journal of Management, 26 (2), $197-210$.

Kotter, J.P., 1995. Leading change: Why transformation efforts fail. Harvard Business Review, $73(2), 59-67$.

Krause, R. 2017. Being the CEO boss: An examination of board chair orientations. Strategic Management Journal, 38 (3), 697-713.

Kuratko, D.F., Hodgetts, R.M., 2007. Entrepreneurship: Theory, Process, Practice, seventh ed. Thomson South-Western Publishing, Mason, $\mathrm{OH}$.

Lorsch, J.W., MacIver, E., 1990. Pawns or potentates: The reality of America's corporate boards. The Executive 4 (4), 85-87.

Lyles, M.A., 2014. Organizational learning, knowledge creation, problem formulation and innovation in messy problems. European Management Journal, 32 (1), 132-136. 
Lynall, M.D., Golden, B.R., Hillman, A.J. 2003. Board composition from adolescence to maturity: A multitheoretical view, 28 (3): 416-431.

Mace, Y.L., 1971. Directors: Myths and Reality. Harvard University Graduate School of Business Administration, Cambridge, MA.

McDonald, M.L., Westphal, J.D., 2010. A little help here? Board control, CEO identification with the corporate elite, and strategic help provided to CEOs at other firms. Academy of Management, 53 (2), 343-370.

Mizruchi, M.S., 1983. Who controls whom? An examination of the relation between management and boards of directors in large American corporations. The Academy of Management Review, 8 (3), 426-435.

Nadler, D.A., Shaw, R.B., Walton, A.E., 1994. Discontinuous Change: Leading Organizational Transformation. Jossey-Bass, San Francisco.

Nadler, D., Tushman, M., 1995. Types of organizational change: From incremental improvement to discontinuous transformation, in: Nadler, D.A., Shaw, R.B., Walton, A.E. (Eds.), Discontinuous Change: Leading Organizational Transformation. JosseyBass, San Francisco, pp. 15-34.

Parker, H., 1990. The company chairman: His roles and responsibilities. Long Range Planning, $23(4), 35-43$.

Patton, M.Q., 2002. Qualitative Research and Evaluation Methods, third ed. Sage, Thousand Oaks, CA.

Pettigrew, A., McNulty, T., 1995. Power and influence in and around the boardroom. Human Relations, 48 (8), 845-873.

Pugliese, A., Bezemer, P., Zattoni, A., Huse, M., Van den Bosch, F., Volberda, H., 2009. Boards of directors' contribution to strategy: A literature review and research agenda. Corporate Governance: An International Review, 17 (3), 292-306. 
Rittel, H.W.J., Webber, M.M., 1973. Dilemmas in a general theory of planning. Policy Sciences, 4 (2), 155-169.

Rechner, P.L., Dalton, D.R., 1991. CEO duality and organizational performance: A longitudinal analysis. Strategic Management Journal, 12 (2), 155-160.

Roberts, J., 2002. Building the complementary board: The Work of the Plc Chairman. Long Range Planning, 35 (5), 493-520.

Roberts, J., Stiles, P., 1999. The relationship between Chairmen and Chief Executives: Competitive or complementary roles? Long Range Planning, 32 (1), 36-48.

Roberts, N., 2000. Wicked problems and network approaches to resolution. International Public Management Review, 1 (1), 1-19.

Romanelli, E., Tushman, M.L., 1994. Organizational transformation as punctuated equilibrium: An empirical test. Academy of Management Journal, 37 (5), 1141-1166.

Sashkin, M., 2004. Transformational leadership approaches: A review and synthesis, in: Antonakis, J., Cianciolo, A.T., Sternberg, R.J. (Eds.), The Nature of Leadership. Sage, Thousand Oaks, CA, pp. 171-196.

Saunders, M., Lewis, P., Thornhill, A. 2009. Research Methods for Business Students, fifth ed. FT Prentice Hall, London.

Saunders, M.N.K., Townsend, K., 2016. Reporting and justifying the number of interview participants in organisation and workplace research. British Journal of Management, 27 (4), 836-852.

Silverman, D., 2013. Interpreting qualitative data, fourth ed. Sage, London.

Spencer Stuart, 2017. UK Board Index. Retrieved February 9, 2017 from: https://www.spencerstuart.com/ /media/pdf\%20files/research\%20and\%20insight $\% 20$ pdfs/ukbi2017_b.pdf. 
Spieth, P., Schneider, S., Clauß, T., and Eichenberg, D. 2018. Value drivers of social businesses: A business model perspective. Long Range Planning, published online May 1, 2018, https://doi.org/10.1016/j.1rp.2018.04.004

Stacey, R.D., 1996. Complexity and Creativity in Organizations. Berrett-Koehler Publishers, San Francisco.

Sundaramurthy, C., Lewis, M., 2003. Control and collaboration: Paradoxes of governance. Academy of Management Review, 28 (3), 397-415.

Tang, J., Crossan, M.M., Rowe, W.G., 2011. Dominant CEO, deviant strategy, and extreme performance: The moderating role of a powerful board. Journal of Management Studies, $48,1479-1503$.

Tang, J., Crossan, M., 2017. Are dominant CEOs the saviors of troubled firms? Long Range Planning, 50 (6), 782-793.

Taylor, B., 2001. From corporate governance to corporate entrepreneurship. Journal of Change Management, 2 (2), 128-147.

Tucker, L., Melewar, T.C., 2005. Corporate reputation and crisis management: The threat and manageability of anti-corporatism. Corporate Reputation Review, 7 (4), 377-387.

Tushman, M.L., Anderson, P., 1986. Technological discontinuities and organizational environments. Administrative Science Quarterly, 31 (3), 439-465.

Tushman, M.L., Newman, W., Romanelli, E., 1986. Convergence and upheaval: Managing the unsteady pace of organizational evolution. California Management Review, 29 (1), $29-44$.

Uhl-Bien, M., 2006. Relational leadership theory: Exploring the social processes of leadership and organizing. The Leadership Quarterly, 17 (6), 654-676.

Weick, K.E., Sutcliffe, K.M., Obstfeld, D., 2005. Organizing and the process of sensemaking. Organization Science, 16 (4), 409-421. 
Westphal, J.D., Fredrickson, J.W., 2001. Who directs strategic change? Director experience, the selection of new CEOs, and change in corporate strategy. Strategic Management Journal, 22 (12), 1113-1137.

Withers, M.C., Fitza, M.A., 2017. Do board chairs matter? The influence of board chairs on firm performance. Strategic Management Journal, 38 (6): 1343-1355. 


\section{Authors Biographies}

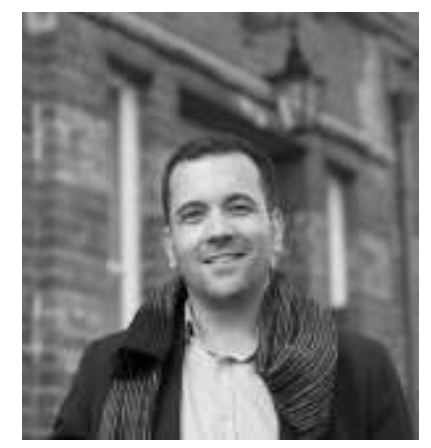

Filipe Morais joined Henley Business School as a Post-Doctoral Fellow in Governance, Leadership and Directorship. Filipe spent 9 years as an HR professional having worked for a variety of firms in the automotive, semiconductor and health industries. His research interests include board dynamics, CEO and Chairperson Leadership, shareholder engagement, top management teams, turnarounds and strategic change. He has been involved in various research projects having significant experience in engaging with board and C-Suite level individuals. Filipe is currently directing a large study into director independence in the UK across commercial, higher education, health, charities and sports organizations. Filipe's research has been published in book chapters, articles, case studies and presented at prestigious international conferences.

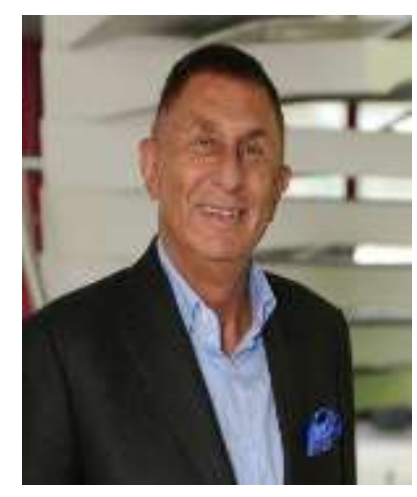

Andrew Kakabadse joined Henley Business School in July 2013 after 30 years at Cranfield School of Management, where he finished as Professor of International Management Development and was awarded the honour of Emeritus Professor., Andrew has consulted and lectured in the UK, Europe, USA, SE Asia, China, Japan, Russia, Georgia, the Gulf States, India and Australia. He was also Vice Chancellor of the International Academy of Management and has been Chairman of the Division of Occupational Psychology, British Psychological Society, 2001. His current areas of interest focus on improving the performance of top executives, top executive teams and boards, excellence in consultancy practice, leadership, corporate governance, conflict resolution and international relations.

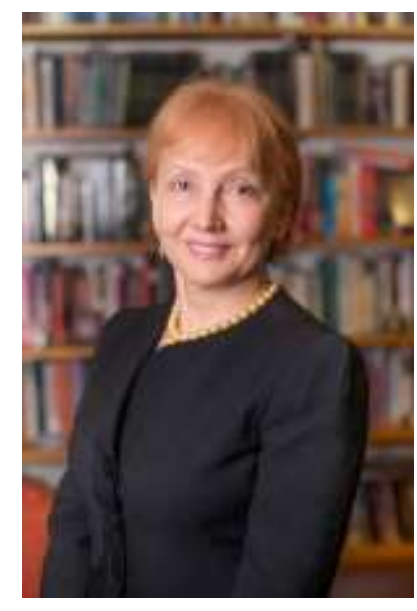

Nada Kakabadse is elected Member of the European Academy of Sciences and Arts and their representative in the UK and Brussels. She has also contributed over 90 chapters to international volumes and has published over 190 scholarly articles. She has co-authored 23 books.

Nada is a Professor of Policy, Governance and Ethics at University of Reading, Henley Business School where she also Heads the Marketing \& Reputation Department.

Nada and her co-authors won the William E. Mosher and Frederick C. Mosher Award for the best article written by an academic in the journal Public Administration Review (PAR) in 2003 as well as best paper of the year in the Journal of Managerial Psychology (JMP) in 1998. 